Prepared for the U.S. Department of Energy

Under Contract DE-AC05-76RL01830

\title{
Topic Brief 4: Above-Code Buildings
}

Updated 12/1/2009

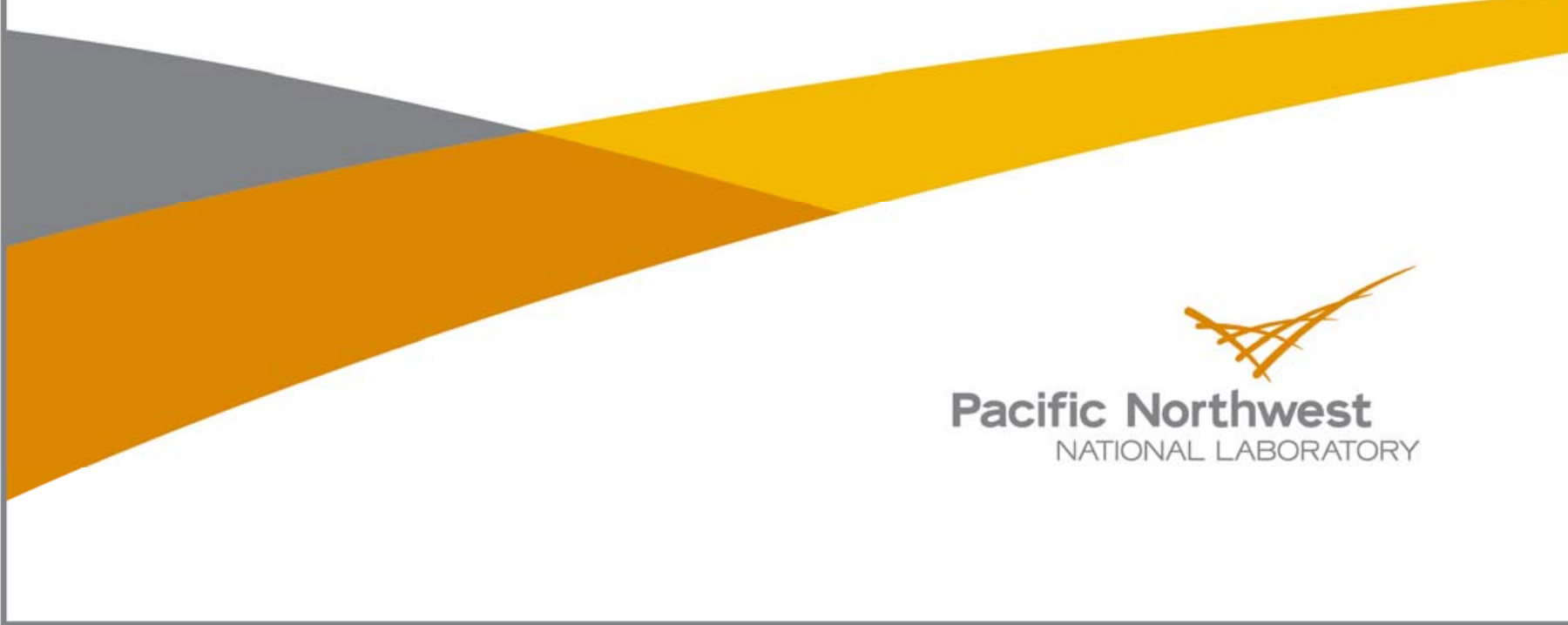




\title{
DISCLAIMER
}

This report was prepared as an account of work sponsored by an agency of the United States Government. Neither the United States Government nor any agency thereof, nor Battelle Memorial Institute, nor any of their employees, makes any warranty, express or implied, or assumes any legal liability or responsibility for the accuracy, completeness, or usefulness of any information, apparatus, product, or process disclosed, or represents that its use would not infringe privately owned rights. Reference herein to any specific commercial product, process, or service by trade name, trademark, manufacturer, or otherwise does not necessarily constitute or imply its endorsement, recommendation, or favoring by the United States Government or any agency thereof, or Battelle Memorial Institute. The views and opinions of authors expressed herein do not necessarily state or reflect those of the United States Government or any agency thereof.

\author{
PACIFIC NORTHWEST NATIONAL LABORATORY \\ operated by \\ BATTELLE \\ for the \\ UNITED STATES DEPARTMENT OF ENERGY \\ under Contract DE-AC05-76RL01830
}

Printed in the United States of America
Available to DOE and DOE contractors from the Office of Scientific and Technical Information,
P.O. Box 62, Oak Ridge, TN 37831-0062;
ph: (865) 576-8401
fax: $(865)$ 576-5728
email: reports@adonis.osti.gov

\begin{abstract}
Available to the public from the National Technical Information Service, U.S. Department of Commerce, 5285 Port Royal Rd., Springfield, VA 22161 ph: (800) 553-6847 fax: $(703) 605-6900$ email: orders@ntis.fedworld.gov online ordering: http://www.ntis.gov/ordering.htm
\end{abstract}

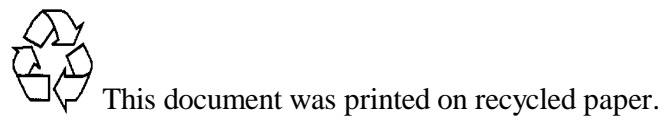




\section{Topic Brief 4: Above-Code Buildings}

Updated 12/1/2009

Prepared for the U.S. Department of Energy under Contract DE-AC05-76RL01830

Pacific Northwest National Laboratory

Richland, Washington 99352 

The American Recovery and Reinvestment Act (Recovery Act) requires the governors to notify the Secretary of Energy that the governor has obtained assurances that the state or applicable units of local government will implement a plan for achieving compliance with building energy code(s) in at least $90 \%$ of the new and renovated residential and commercial building space. The Department of Energy's (DOE's) Building Energy Codes Program (BECP) is developing procedures and tools for measuring compliance as required in this legislation. Two drafts of a State Compliance Evaluation ("Strawman") document were developed and made available to stakeholders for their review and feedback in March and June 2009. Feedback received on the second Strawman document included the following topics, both of which pertain to above-code buildings:

- One respondent indicated a desire to include the impact of buildings that exceed code requirements in determining a state average. For example, a building that exceeds code requirements could be used to offset the results of a building that did not comply.

- Above-code, voluntary market-driven programs, such as Energy Star, HERS and LEED, were mentioned as being quite active in some states. The BECP was encouraged to provide tools and guidelines which adequately include and leverage building evaluations performed as part of these programs.

These related issues are discussed in the following sections.

\section{Incorporation of Above-Code Buildings}

The language in Section 410 of the Recovery Act is clear in that the measurement asked for is compliance with the state or local government building energy code(s):

"A plan for the jurisdiction achieving compliance with the building energy code or codes described in subparagraphs (A) and (B) within 8 years of the date of enactment of this Act in at least 90 percent of new and renovated residential and commercial building space. Such plan shall include active training and enforcement programs and measurement of the rate of compliance each year"

While above-code buildings and programs are encouraged, they are voluntary, market-driven programs that are not minimum law that all buildings would have to satisfy. The BECP believes the goals of this effort are to understand and improve code compliance, which, where applicable, is considered a mandated baseline for new construction. If $50 \%$ of the buildings are above-code by a given amount, and $50 \%$ of the buildings are below code by that same amount, the goals of this effort would be to bring the below-code buildings into compliance. If the state compliance rate in this example was deemed to be $100 \%$, that would indicate $100 \%$ of the buildings were compliant with the code, which is not the case. It also would imply that corrective measures were not needed, which also isn't the case.

Additionally, evaluation of the degree to which a building exceeds the code is not feasible, given the code's prescriptive nature. This could only be accomplished by simulating or measuring building performance. The State Compliance Evaluation (Strawman) Rev 2 tried to emphasize the reasons that performance measurement would be considered out of scope for this effort:

“...a performance-based evaluation of metered energy consumption of existing buildings would be a major undertaking, potentially very expensive, and it is unclear how it could be directly and readily applied to derive compliance metrics. If the codes were purely performance-based rather than prescriptive, this might be feasible. But currently there are a number of factors which could dramatically affect building energy use and are not addressed in a prescriptive code or standard, such as the climate conditions, use, occupancy schedule, and operations and maintenance activities. The results of such a study would additionally be subject to considerable discussion and debate." 
Compounding consideration of above-code buildings is not only measurement of how much better they are than minimum code, but making defensible assumptions about how many of the total buildings in the state were designed and constructed under the above-code program(s).

There is value in attempting to look at the performance of evaluated buildings, and several previous state studies have attempted to so in various ways. A list of such studies and summary of the methods used to accomplish this will be included in the "Related Outcomes" section of the BECP compliance guidelines. However, these efforts do not yield results that the BECP feels could be directly applied to the state compliance metrics.

\section{Above-Code Programs}

An attempt will be made to ensure the BECP checklists, guidelines, and tools are integrated with existing abovecode programs, such as Energy Star, Residential Energy Services Network (RESNET), and Leadership in Energy and Environmental Design (LEED). The BECP will attempt to understand the data collected from major abovecode programs and to advise how that data can be used in building evaluations for this effort. The BECP fully intends to offer representatives from these programs an opportunity to participate in these efforts. Perhaps the greatest opportunity to leverage existing above-code programs is to utilize their workforce as evaluators for this effort. The additional training and certification that might be needed for existing above-code raters is discussed in Topic Brief 3, Onsite Compliance Evaluations.

The BECP also received comments indicating that the data collected in these code compliance evaluations could contribute to above-code programs, such as in developing a more robust national Commercial Building Energy Consumption Survey (CBECS). Opportunities to pursue data sharing efforts will be discussed in more detail in the "Related Outcomes" section of the BECP guidelines. 